\title{
A FUNDAMENTAÇÃO METAFÍSICA DO DIREITO OCIDENTAL E A SUA CRISE RADICAL NO CONTEXTO DO RELATIVISMO PÓS-MODERNO
}

\author{
Prof. Dr. Antonio Nedel
}

\section{RESUMO}

O pensamento jurídico ocidental desde a antiguidade clássica até a modernidade desenvolveu epistemologicamente um conceito de direito fundamentado nos pressupostos da racionalidade metafísica. Razão pela qual a crise do relativismo pós-moderno que hoje abala e fragmenta as lógicas certezas da metafísica, atinge radicalmente o direito, ameaçando a sua histórica finalidade e evidenciando a possibilidade real do seu desaparecimento, num contexto cultural que está a exigir formas de regulação social mais adaptadas às complexas exigências das sociedades tecnológicocientíficas.

Palavras-chave: Crise. Direito. Metafísica. Modernidade. Pósmodernidade.

\section{INTRODUÇÃO}

Propõe o presente artigo uma reflexão crítica sobre a relação entre a metafísica e o direito ocidental, tendo presente a crise radical que a ambos atinge no contexto cultural da pós-modernidade.

Fundamentada na redução objetificante do conceito de verdade, propiciada pelo universalismo lógico-dogmático do idealismo platônico, a metafísica clássica embasou, ao longo dos séculos, o pensamento jurídico do ocidente. Mesmo o positivismo jurídico, em que pese seu afã de exorcizá-la cientificamente, acabou assimilando-a e constituindo-se como uma metafísica ao contrário, numa reafirmação às avessas de Platão.

No entanto, com o advento da cultura pós-moderna, as verdades fundamentadas na racionalidade metafísica vêem-se abaladas por um relativismo fragmentário que corrói os alicerces da sua universalidade, diluindo o real numa aleatória transitoriedade contingente.

Dessa forma, uma crise de sentido gerada pelo vazio da metafísica atinge todo o modelo civilizatório do ocidente nela fundamentado. Como não poderia deixar de ser, o direito, enquanto expressão cultural dessa civilização, também é atingido e conhece hoje a mais grave crise da sua história. 
$\mathrm{Na}$ verdade, a radicalidade da crise vai ao ponto de ameaçar a própria supressão do direito e da sua histórica finalidade, isto é, a possibilidade real do seu desaparecimento, vindo ele a ser substituído por outros reguladores sociais mais adaptados às exigências das sociedades técnico-científicas do nosso tempo.

De nossa parte, pensamos que a superação da metafísica não condena o direito a um vazio axiológico que significa, na prática, a sua negação, razão pela qual, para além do universalismo dogmático-metafísico e da redução do direito ao hipercientificismo tecnológico propomos, ao final dessas reflexões, uma recuperação crítica na qual entendemos estar o seu verdadeiro e humano sentido.

\section{A FUNDAMENTAÇÃO METAFÍSICA DO DIREITO PRÉ-MODERNO}

A estrutura epistemológica do pensamento jurídico ocidental, funda suas raízes na tradição de uma metafísica objetificante que tem sua base no racionalismo idealista de Platão. Em imanência com esta concepção, a idéia de direito deriva de uma abstração transcendental que limita o fenômeno jurídico ao plano entificado de uma normativa axiologia. Tal proposição, sistematicamente definida nos termos de uma dogmática legalidade positiva, tem a missão de reger a vida social segundo critérios lógicos a priori definidos.

Assim, as leis, como expressão da virtude total, transformam-se em fonte axiológica e amálgama metafísico das estimativas político-jurídicas da polis, por serem a materialização da hegemonia do espírito e da reta razão.

Dessa forma, antecipando a crença do positivismo legalista, Platão identifica, na obediência às leis, a consumação dos fins do Estado, por serem elas a objetivação de um juízo de valor transformado em preceito universal, logo, a prudência determina a incondicional subordinação aos seus postulados que manifestam a essência do bem e do justo no formalismo abstrato das suas hipotéticas premissas.

Justificada então, nos termos ôntico-fundantes do seu idealismo transcendental, as leis assumem absoluta e dogmática primazia na vida dos cidadãos, como o próprio filósofo assevera: "En primer lugar, pues, se encontran la ciudad, la constitución y las leyes ideales". ${ }^{1}$

Embora criticada e, em alguns momentos, renegada, a metafísica platônica constituiu o fundo paradigmático de todo o pensamento jurídico ocidental que o sucedeu, estando inclusive na base da aspiração de segurança e certeza jurídica da concepção que tentou banir a metafísica do direito: o positivismo jurídico.

Neste sentido, a fundamentação prático-prudencial do direito desenvolvida por Aristóteles, em que pese o pendor realista da sua epistemologia priorizar a sensibilidade empírica através de uma filosofia 
prática, culminou platonicamente num idealismo metafísico de base onto-teológica, evidenciando a vinculação ontológico-normativa com a transcendência idealista que ele quis superar.

Se é verdade, como reconhece Heidegger, que Aristóteles "[...] hizo descender de su lugar supraceleste a las ideas que flotaban libremente y las transplanto a las cosas reales"2, verifica-se, nos desdobramentos dialéticos do seu pensar prático-jurídico, o mesmo fundamento ético-metafísico que imanta a partir da sua transcendência, de forma dogmático-reducionista, as possibilidades de existência moral do indivíduo que, impossibilitado de autodeterminação, deve submeter-se, incondicionalmente, aos ditames normativos do poder político, pois, se enquanto portador do logos, o homem não está submetido ao determinismo normativo-causal da natureza, a possibilidade de constituir-se em ente político exige-lhe a identificação ontológica com a essência metafísica da pólis: "Quem for incapaz de se associar ou que não sente essa necessidade por causa da sua autosuficiência, não faz parte de qualquer cidade e será um bicho ou um deus". ${ }^{3}$

Nos termos da teleologia prática aristotélica, a lei jurídica, enquanto expressão racional da ética deve moldar a consciência moral dos cidadãos e submetê-los coercivamente ao império da sua axiologia, da mesma forma como, em Platão, o seu fundamento ético-metafísico legitima-se, em última instância, apoiado no argumento teológico como expressão da suprema razão: "[...] exigir que a lei tenha autoridade não é mais que exigir que Deus e a razão predominem"4, o que equivale a dizer que o justo legal, na sua contingência e variabilidade, deve fundamentar-se no justo natural, que é eterno e imutável.

Esta imanência legitima a soberania das leis, desvinculando-as do plano das paixões que movem as contingências do poder político, vinculando-as aos princípios transcendentes que vigem eternamente na abstrata axiologia metafísica do seu ser.

O mesmo fio condutor da essência metafísica que, partindo das mais profundas raízes da reflexão jurídica grega, identificou, num primeiro momento, o direito em imanência com a phýsis, refundiu-o no objetivismo lógico-abstrato do idealismo de Platão, ampliou-o na filosofia prática de Aristóteles, também se fez presente no contributo do pensamento estóico, no qual "[...] o ôntico naturalismo prático-racional generaliza-se num universal racionalismo ontológico-normativo e compreende-se como o sentido de uma eterna lei racional"5. Por meio do pensamento estóico que explicitou o jusnaturalismo ${ }^{6}$, fundindo uma compreensão cosmológico-racional da lei da natureza, em unidade com os princípios eternos da reta razão, pôde o pensamento jurídico romano, como que encerrando o ciclo clássico da racionalidade metafísica, vislumbrar, como fundamento de validade da lex civilis, os princípios eternos e imutáveis da lex naturalis, agregando, na compreensão do jus, o equilíbrio harmônico e prático-prudencial de uma ordem racional que, rompendo com os laços formais dos ritos arcaicos do direito quiritário, elevou o direito ao estatuto de razão escrita: "[...] el Derecho no es ya la orden inflexible del orden público, la regla impuesta y absoluta: su fundamento no es ya la autoridad, sino la razón: la idea del Derecho llegó a ser eminentemente filosófica". ${ }^{7}$ 
Embora com o influxo autoritário da palavra divina, o logos metafísico da clássica compreensão prático-prudencial do direito também se manteve na base da reflexão jurídica medieval.

Tomás de Aquino, ao caracterizar a metafísica como a ciência suprema, identifica-a como o resultado hermenêutico de uma lógica dedução da perfeição de Deus, que é onipotente e absoluta: "Deus encerra em si as perfeições de todos os seres e, por isso, é denominado ser universalmente perfeito". ${ }^{8}$ Logo, por conta da absoluta perfeição divina, todos os entes do universo estão submetidos ao domínio da sua governabilidade; "[...] assim como nada pode existir sem ser criado por Deus, assim também nada há que Ihe possa escapar ao Governo". ${ }^{9}$ Se a vontade de Deus que tudo governa é o fim último da vida, e para ela devem convergir todas as ações humanas, orientadas pelos critérios prudenciais da reta razão, por decorrência lógica, a idéia de direito tem por fonte o princípio imponderável e metafísico de uma lei não promulgada; " $E$ como a razão divina nada concebe temporalmente, mas tem o conceito eterno, conforme a Escritura, é forçoso dar a essa lei a denominação de eterna"10. Toda prescrição normativa que contrariar os dogmáticos princípios derivados desta metafísica transcendência não será considerada lei, mas corrupção.

Portanto, o justo legal apenas se justifica enquanto materialização prudencial do justo perfeito contido na lei eterna, evocando, assim, a aspiração apolínea e eudemonista da racionalidade clássica; a concepção tomista da razão prática, como fundamento metafísico do direito, expressa a manifestação humanizada da vontade, da verdade e da justiça divina, convergindo também, onto-teologicamente, para um dogmatismo legal.

Esse legalismo, apoiado no dogma metafísico da revelação divina, imprimiu ao pensamento jurídico medieval uma índole exegético-textual, que se valia da razão para afirmar, logicamente, o argumento irrefutável da autoridade sagrada dos textos, que "[...] não são tidos como testemunhos históricos da verdade ou da realidade das coisas, mas como estas verdade e realidade em si mesmas". ${ }^{11}$

Dessa forma, o caráter não-investigativo, mas meramente descritivo, isto é, exegético-interpretativo do pensamento jurídico medieval, hermeneuticamente submisso aos textos da autoridade a priori estabelecidos, antecipa a concepção lógico-dedutiva do positivismo legalista.

Nesse sentido, o pensamento jurídico moderno, embora tenha constituído uma nova dimensão epistemológica para o direito, ao romper os laços ético-ontológicos com a teologia em nome da autonomia humana, manteve-se ainda nos quadros da tradição metafísica.

Nos termos da homologia instaurada pela racionalidade moderna, a idéia de direito natural, que a tradição identificava na transcendência onto-teológica de uma eterna e imutável orientação axiológico-normativa, submete-se agora aos pressupostos hipotético-dedutivos de uma ordem lógico-analítica fundamentada na autonomia da razão. 
A universalidade formal visualizada pelos axiomas dessa razão autofundamentante priorizou a satisfação dos interesses individuais e engendrou um pensamento ético-jurídico voltado para o solipsismo egoísta de um homem auto-suficiente: "A universalidade dos direitos que deriva do Direito natural moderno é fundada no postulado igualitarista, ou seja, na igualdade dos indivíduos enquanto unidades isoladas, numericamente distintas no estado de natureza." 12

A racional formalização abstrata do direito, se coerente do ponto de vista lógico, levantou o problema da legitimidade das normas positivas, contradição que Kant procurou resolver, afirmando que a liberdade e as normas jurídicas dela derivadas deveriam ter a sua fonte axiológica nos princípios da razão pura. $^{13}$

Perfilando a mesma linha de transcendência idealista, Hegel acentuou que o princípio político-jurídico máximo do Estado, enquanto expressão materializada da razão universal, deve viabilizar e permitir "[...] que o espírito da subjetividade chegue à extrema autonomia da particularidade pessoal"14, e a contradição derivada da liberdade que, em princípio, opõe indivíduo e sociedade, resolve-se na medida em que a liberdade individual só pode realizar-se sob a égide axiológica da normatividade jurídica universal imposta pelas leis do Estado, entendido como um ente moral absoluto. Assim, identificada com a racionalidade puramente formal do jusnaturalismo modernoiluminista, a dialética hegeliana repristina os termos transcendentais da abstrata objetificação metafísica de Platão na sua concepção jurídica.

\section{A ILUSÃO METAFíSICA DO POSITIVISMO JURÍDICO NO PARADOXO DE UMA METAFÍSICA AO CONTRÁRIO}

Gestado a partir do humanismo renascentista e ganhando forma lógica com o rigor abstrato do racionalismo do século XVIII, o positivismo surgiu, no século XIX, como uma atitude epistemológica identificada com o paradigma da ciência empírica.

A nova visão de mundo identificada com os princípios do positivismo propunha-se instaurar uma definitiva civilização de base científica, depurada dos sofismas derivados da fantasmagoria metafísica.

Augusto Comte, principal arauto da nova era, ao analisar todas as fases em que se desenvolveu a inteligência humana, anunciou a descoberta de uma grande lei, uma lei fundamental, que, perpassando toda a história da civilização, evidencia que cada ramo do conhecimento passou por três estados históricos diferentes: "[...] estado teológico ou fictício, estado metafísico ou abstrato, estado científico ou positivo". ${ }^{15}$

Reconhecendo no estado teológico o primeiro movimento reflexivo da inteligência humana na busca da explicação da realidade, Comte observa que o mesmo, ao lançar mão de divindades transcendentais para a explicação dos fenômenos, afasta-se da possibilidade de uma compreensão verdadeira. Já no 
estado metafísico, a equivocada pretensão de explicação absoluta da realidade mantém inalteradas as contradições do estado teológico, transladando apenas a fonte da verdade dos agentes sobrenaturais para a força humana da racionalidade abstrata. Finalmente, no estado positivo, a maturidade do espírito humano, reconhecendo a impossibilidade de atingir o conhecimento absoluto, reduz-se, conscientemente, em descobrir cientificamente as leis que regem os fenômenos.

No entanto, ao explicar o espírito fundamental do positivismo enquanto verdadeira filosofia, Comte assevera que ele deve ter a pretensão de sistematizar toda a existência humana: "Para essa comum destinação fundamental, o ofício próprio da filosofia consiste em coordenar entre elas todas as partes da existência humana, a fim de conduzir a noção teórica a uma completa unidade"16, tendo em vista que "[...] toda sistematização parcial seria necessariamente quimérica e insuficiente". ${ }^{17}$ Assim, contrariando sua motivação inicial, a filosofia positiva evolui para um fundamento metafísico, como acentua Habermas. Embora o positivismo tenha substituído a plenitude da metafísica clássica por uma relativização submissa a leis empíricas reguladas em imanência causal, sua interpretação continua prisioneira da metafísica, pois "Os elementos da tradição metafísica são, assim, conservados na polêmica positivista; eles tão-somente alternam seu peso valorativo."18

Na verdade, em seu afã de exorcizar a metafísica a priori, o positivismo iludiu-se a si mesmo, inconsciente de que está na sua essência por ela maculado, eis que "[...] o positivismo só pode exprimir-se, em termos compreensíveis, através de conceituações metafísicas. Ao desfazer-se delas sem as refletir, tais conceituações mantêm sua têmpera substancial também contra o adversário". ${ }^{19}$

Identificado com os princípios epistemológicos do paradigma positivista, o positivismo jurídico dele derivado, igualmente, partilhou da "[...] aversão à especulação metafísica e à procura das razões finais". ${ }^{20}$ Nesse sentido, ao estabelecer um conceito de direito reduzido ao âmbito estrito das normas positivas, passou a acusar de metajurídica qualquer abordagem de índole axiológica que tivesse a pretensão de questionar sua dogmática legitimidade.

Tal atitude epistemológica, como observou Perelman, ${ }^{21}$ culminou na oposição entre direito natural e direito positivo, e, assim, desvinculada da fundamentação de validade que Ihe propiciava a ética jusnaturalista, a ordem jurídica positivista teve que extrair a sua validade de si mesma, ou seja, a norma jurídica não mais se fundamenta numa validade pressuposta, mas institui a validade a partir de suas prescrições, isto é, das prescrições normativas oriundas da vontade do legislador político, como expressão abstrata de uma hipotética vontade geral, nos termos de uma redução objetivo-formal, a lei se absolutiza como única fonte do direito, autonomizando o jurídico da metafísica jusnaturalista no âmbito de um estado civil em que "[...] todos os direitos são fixados pela lei". ${ }^{22}$

E, assim, o logicismo abstrato do idealismo platônico, que sempre se mantivera como pano de fundo da fundamentação do pensamento jurídico ocidental reafirma-se, com toda a força, na concepção lógico-abstrata do 
positivismo jurídico, que, se, por um lado, desvinculou o jurídico dos pressupostos éticos da filosofia prática, por outro, constituiu-se na mais perfeita e acabada expressão da metafísica objetificante que, a partir do racionalismo cartesiano, instituiu o paradigma científico da modernidade.

Ao tentar materializar o desiderato comteano de banir a metafísica, exorcisando axiomaticamente as ambigüidades, para propiciar uma lógica certeza e segurança nas operações metódicas, também o pensamento jurídico positivista, iludido da sua própria essência, acabou se constituindo numa metafísica ao contrário. Sua essência metafísica evidencia-se na compreensão de que uma ordem jurídica deve constituir um mundo fechado dogmaticamente em si mesmo, um mundo autônomo, que subsiste na abstrata transcendência lógica de um todo sistemático, ou seja, da mesma forma que qualquer dogmatismo teológico-metafísico, a metafísica cientificista do positivismo jurídico reduziu a possibilidade da verdade ao âmbito dogmático de um sistema fechado.

Portanto, se o ideal de certeza e segurança do conhecimento, propiciado pelo logicismo abstrato da metafísica platônica esteve na base de toda construção cultural do ocidente, também a idéia de direito, enquanto produto cultural dessa tradição, erigiu-se em imanência com os seus princípios.

Julgando ser o seu antípoda, o positivismo jurídico manifestou-a na sua negação, iludido, sem saber que a trazia na essência dos seus pressupostos, pois, através da radical positivação normativa de um abstrato dogmatismo legalista, impôs uma metafísica ao contrário, reafirmando Platão às avessas na transcendente ilusão de que uma justeza lógica propicia, a partir da sua coerência formal, uma também justeza material. Assim, ao construir um mundo jurídico, no âmbito monista de um sistema fechado, que se consumou lógicocientificamente na redução objetificante de uma metafísica subjetivo-teorética, o positivismo jurídico transformou o direito numa técnica de controle social e, também, por conseqüência, ao confinar o saber jurídico aos limites dogmáticos do seu sistema normativo, reduziu o jurista à condição de técnico, a quem apenas compete conhecer e aplicar formalmente, sem questionar os seus fins, a vontade do legislador. Como observou Sérgio Cotta, "Da teorização oitocentista da école de l'exégése e da "jurisprudência analítica" de John Austin à novecentista da "doutrina pura" de Hans Kelsen, foi-se delineando e precisando, sempre com maior rigor e conscientização, a figura do jurista como puro técnico". ${ }^{23}$

A partir dessa instrumentalização técnica, que o transformou numa entidade formal destinada a delimitar burocrático-normativamente os objetivos do poder político, o direito perdeu sua autonomia e, subsistindo neutralmente na redoma dogmático-metafísica de um abstrato sistema fechado, alienou-se das contingências práticas da realidade e separou-se da historicidade do mundo da vida. 


\section{A SUPERAÇÃO DA METAFÍSICA E A CRISE RADICAL DO DIREITO}

Quando Hegel afirmou que "[...] nosso tempo é um tempo de nascimento e de passagem para um novo período" 24 , estava assumindo a condição de arauto da superação da metafísica que nele se consumava; Embora, coube ao gênio trágico de Nietzsche o papel de verdugo das dogmáticas certezas da metafísica moderna.

Efetivamente, a crise da razão que confluiu para o seu pensamento, articulou-se numa crítica radical ao império da subjetividade lógico-abstrata, levando Heidegger a afirmar que "[...] lo que metafisicamente tienne su principio con Descartes comienza con Nietzsche la historia de su acabamiento"25, prenunciando o relativismo axiológico e a marca nilista que evidencia a cultura contemporânea.

Assim, como decorrência inevitável da desconstrução e superação da metafísica, uma crise de sentido se alastra pelo emergente pensamento pósmoderno que se impõe como um mosaico de esboços fragmentários, onde se abandona a busca de uma verdade universal em favor de um cético jogo aleatório seduzido pela transitoriedade contingente. Em função disso, agora, a crise transcende o que historicamente fora uma disputa entre escolas, pois as divergências circunstanciais jamais haviam abalado a premissa metafísica que imantava toda a racionalidade.

Com a decomposição das cosmovisões religiosas e metafísicas, lembra Habermas, "[...] não temos outra maneira de juntar - e reequilibrar - aquilo que, em nível de interpretação cultural, se pulverizou em diferentes aspectos de validez" ${ }^{\prime 26}$. Na verdade, podemos dizer com Albrecht Wellmer que a crise da razão que vivenciamos, parece apontar para o definitivo final de um projeto histórico: "[...] el proyecto de la modernidad, el proyecto de la ilustración europea, o incluso, por último, el prospecto de la civilización greco-ocidental'. ${ }^{27}$

Por sua vez, o direito, enquanto expressão cultural dessa civilização, também se vê frontalmente e radicalmente atingido pela crise gerada em função da desintegração das dogmáticas certezas propiciadas pela racionalidade metafísica que sempre fundamentaram o seu conceito.

Igualmente, no contexto das transformações econômicas, políticas, culturais, sociais e ecológicas em curso que estão abalando os mais profundos alicerces do nosso modelo civilizatório, também vai soçobrando o conceito de Estado-Nação, num mundo globalizado onde se liquefazem as noções de soberania e cidadania.

Efetivamente, os poderosos interesses econômicos transnacionais derrubam fronteiras geográficas, ignorando as identidades nacionais e suas instituições político-jurídicas, originando situações de choque com as estruturas jurídicas estatais e seu aparato processual-burocrático. Este continua formalmente vinculado a princípios hierárquicos de legalidade e segurança jurídica, embora seu poder de controle e decisão, cada vez mais é pressionado e abalroado por uma "[...] pletora de entidades multilaterais, organizações 
transnacionais, grupos nacionais de pressão, instituições financeiras internacionais, corporações empresariais multinacionais, etc." . ${ }^{28}$

Todo esse conjunto de pressões levadas a efeito junto aos governos nacionais, por entidades internacionais como o Grupo de Investidores Estrangeiros (GIE) vão impondo uma gradativa informalização dos sistemas jurídicos nacionais. Contudo, em face das exigências da globalização econômica, redefinem-se conceitos jurídicos a par com a desregulamentação do mercado e programas de desestatização, num contexto de flexibilização que aponta para a deslegalização e desconstitucionalização do direito.

Nesse contexto, procedimentos democráticos institucionalizados são minados, juntamente com a segurança jurídica e os direitos adquiridos constitucionalmente. A própria democracia se dissolve submetida ao império do capital financeiro internacional que impõe formas cada vez menos transparentes no processo de elaboração das normas jurídicas, por estar a razão política submetida aos critérios corporativos da vontade econômica que condiciona também a vida jurídica.

Sendo assim, sob a égide do relativismo desconstrutivista que vitima a autonomia e a soberania do Estado-Nação, também a idéia de direito com ele identificada desde o século XVII vê-se frontalmente atingida. Nessa medida, se constata a emergência de um paradigma jurídico desvinculado da pretensão metafísico-universalista no qual a partir do jusracionalismo, lógiconormativamente axiomatizou-se o direito em termos racionais e sistemáticos.

Liberto da metafísica subjetividade dogmático-abstrata e dos ideais de certeza e segurança jurídicos por ela propiciados, o direito pós-moderno se determina por um pragmatismo voluntarista e relativista. Assim, o problema do risco assoma num contexto de complexidade e pluralismo racional que evidencia a superação do monismo legalista estatal como fonte absoluta do direito, numa realidade social em que subsistemas normativos funcionam paralelamente como formas de regulação alheias e, muitas vezes, contrárias aos mandamentos jurídicos da regulação estatal.

Resulta de toda essa conjuntura problemática, uma crescente complexidade a envolver o fenômeno jurídico, a qual, tendo por fonte uma realidade social que a orfandade de metafísica desagregou, não reconhece mais na universalidade normativo-jurídica do direito positivo estatal a plenitude do direito. O pluralismo resultante dessa complexidade cada vez mais dificulta a possibilidade de redução da juridicidade à simplicidade lógica da razão moderna.

Como observa Arnaud ${ }^{29}$, a complexidade se evidencia na prática quando - legislador já não sabe se convém desregular, nem o que desregular, nem tampouco que regulação deve substituir o que foi desregulado, num contexto colossal de conexões emaranhadas e dados contraditórios, numa ordem jurídica coabitada por diversos subsistemas informais de regulação jurídica.

Uma alternativa lógica para compossibilitar a complexa coexistência simultânea deste pluralismo normativo num sistema jurídico aberto que, 
pressupondo sua intrínseca mobilidade, reduza a sua objetivação formal, disciplinando-a por meio de uma heterônoma planificação propiciada pela racionalidade cibernética, nos é oferecida pela teoria dos sistemas de Luhmann, que é "[...] hoy em dia, um concepto unificador de significados y niveles de análises muy diversos" ${ }^{30}$.

$\mathrm{Na}$ verdade, uma super teoria que permite a democrática centralização das diferenças num contexto de mutação paradigmática. Para Luhmann, a formação do direito encontra base e justificação através de uma extensa mobilidade e, mesmo possuindo a sociedade uma legislação centralizada por não ter condições de encarregar-se dos sistemas jurídicos paralelos, criados nas diversas organizações, sua responsabilidade deve generalizar-se levando em consideração a complexidade normativa da globalidade do sistema.

As perspectivas da positivação do direito nesta realidade situam-se num plano abaixo do todo social. Por isso a complexidade tende a aumentar, gerando outra dimensão de problemas para os quais o convencionalismo da dogmática jurídica tradicional resulta inadequado. Ou seja, "[...] a maior complexidade da sociedade e do seu direito, a disponibilidade de muitas outras possibilidades tem que constituir a base para a institucionalização de novas formas de encaminhamento que sejam ao mesmo tempo ainda mais generalizantes"31.

Isso posto, para poder adaptar-se ao ritmo da complexidade pósmoderna o direito deve levar em consideração a mobilidade intrínseca que ela revela, condicionando-se ciberneticamente aos limites de uma variação controlada, onde se abre espaço para uma adequação tecnológica dos problemas jurídicos que, conduzidos em termos algorítmicos e gradativamente automatizados, permitem uma simplificação do processo decisório através da mecanização do seu procedimento.

No seu esforço de integrar o fenômeno jurídico ao contexto da realidade pós-moderna, a teoria sistêmica do direito procura refleti-lo levando em consideração os inúmeros impulsos normativos que partem de diversos centros emitentes, englobando através de um sistema informativo a complexa pluralidade das operações econômicas, político-sociais e culturais numa configuração esquemática que permite articular lógico-racionalmente 0 feedback entre os diversos subsistemas que compõem a globalidade do sistema normativo. Busca-se, assim, uma oportuna correspondência do direito com a realidade empírica, adaptando seus mecanismos ao ambiente, adequando-se a ele e absorvendo sua mobilidade normativa nos termos racionais-cibernéticos de uma auto-regulação sistêmica.

Dessa forma, como uma expressão da dialética interna que movimenta todo o complexo normativo das sociedades pós-industriais, o direito assume uma vigência variável, perspectivando uma generalização coerente das diferentes expectativas que se impõem normativamente. Os dispositivos de autocontrole cibernéticos permitem a constância do sistema na grande complexidade do mundo em mutação e, assim, a alternativa proposta por Luhmann visa funcionalizar o direito num contexto cibernético de racionalidade programada, com o intuito de conformar a contingência, planificando-a 
estratégico-sistematicamente no âmbito de um sistema aberto que, pressupondo uma indeterminação prático-empírica, busca superá-la através de um lógico decisionismo propiciado pela racional-técnica redução da complexidade, culminando numa estratégico-tática e conseqüente adequação aos fins políticos socialmente programados.

A tese de Luhmann, no entanto, conduz a uma aporia que a pergunta formulada por Teubner tão bem explicita: "[...] se optarmos pela via trilhada por Luhmann e adotarmos um conceito específico de autopoieses social, em breve deparamos com um novo problema: onde é que encaixa o direito aqui?" ${ }^{32}$. Por óbvio, o funcionalismo cibernético-sistêmico ao submeter e adequar o direito aos domínios analíticos e planificados de uma racionalidade algorítmica, com a pretensão de propiciar sistemas sociais auto-regulativos adaptáveis às exigências do meio ambiente, através de uma instrumental mecanização das condutas em termos de operatórias objetivo-tecnológicas, acaba usurpando a autonomia do direito, transformando-o em simples ferramenta ao serviço do finalismo político-programático. Conforme Jesus Ballesteros, "[...] en un mundo instrumentalista en el que sólo son valoradas herramientas es lógico que el derecho solo apareza justificado en cuanto sea convertido en una herramienta mas, es decir, en algo que puede ponerse al serviço de diferentes fines"33.

Resta claro que o novo tipo de direito que as sociedades contemporâneas, condicionadas pela dinâmica da ideologia científicotecnológica, estão a exigir, pressupõe uma ordem social planificada e programada em termos estratégico-sistemáticos que o instrumentalismo da racionalidade tecnológica viabiliza e torna eficiente, cada vez mais convoca o jurista à consideração de questões técnicas desvinculadas do histórico sentido do direito, gerando, como observa Castanheira Neves, a paradoxal situação de vivermos uma ordem de direito onde "[...] o instrumental finalismo e o esvaziamento de mera tecnicização essencialmente anulam o seu significado ou transformam noutra coisa"34. Portanto, para além das parciais divergências das interpretações fundamentadas na tradição do jusnaturalismo e do positivismo jurídico, a crise radical do direito no ambiente cultural da pósmodernidade ameaça a própria possibilidade da prossecução histórica do seu sentido, evidenciando a possibilidade real do seu desaparecimento no contexto de uma racionalidade social que está a exigir outros reguladores sociais mais adaptados às suas exigências.

Refletindo sobre a perda de sentido do direito que a sua redução ao estatuto de simples técnica de controle social destituída de fundamento normativo evidencia, Castanheira Neves aponta alternativas reais que se propõem substitutivas ao direito, realçando que: "[...] à ordem de validade do direito opõe-se tanto a ordem de necessidade do poder, como a ordem da possibilidade da ciência (ciência-tecnologia) e ainda a ordem de finalidade da política"35. Sendo assim, a adaptação e redução instrumental do direito aos empírico-sociais desideratos do finalismo político, ao anularem a autonomia que o direito reivindica para ser direito, acaba promovendo na prática a sua histórica supressão. Nesse sentido, também Habermas alerta que quando a política se vale do direito para atingir seus fins, destrói-se a função que é própria do direito, eis que: "[...] o direito não pode diluir-se em política, pois, 
neste caso, as tensões entre faticidade e validade, que lhe é inerente, bem como a normatividade do direito se extinguiriam" ${ }^{36}$.

Logo, quer no funcionalismo político, onde o direito se reduz à condição de instrumento político, quer no funcionalismo social que o adapta tecnologicamente a um liberalismo pragmático-utilitarista, nos termos de uma estratégia lógico-cibernética, como também no funcionalismo sistêmico que o distingue autopoieticamente como um subsistema social, utilizado para sistematizar a contingência através de uma desproblematizante redução da complexidade, como nos esclarece a crítica de Castanheira Neves ${ }^{37}$, temos solapada a autonomia e o sentido normativo que caracteriza o direito como direito.

Por conseguinte, se a racionalidade técnico-científica no âmbito redutor de uma cibernética planificação social nega o direito, impõe-se hoje ao pensamento jurídico a busca de alternativas para o direito que transcendam a dimensão da sua lógica instrumental. Nessa acepção, também Recaséns Siches assinala o grave erro de se haver transladado para o campo jurídico os critérios da razão matemática, ao mesmo tempo em que convoca o pensamento jurídico a retomar o caminho correto para "[...] retictificar los desmanes y estragos de aquel imperialismo de la razón matemática y para traer las cosas al lugar que justificadamente les corresponde"38.

Em qualquer época histórica, o caminho que conduz criticamente ao direito deverá transcender a contingência parcial de determinados interesses político-sociais que o transformam em elemento coativo-burocrático de instrumentalização finalística, pois o seu fundamento normativo identifica-se com a dimensão ético-antropológica da condição humana, como encarnação da substantividade material e axiológico-existencial que lhe dá sentido ao mesmo tempo ontológico-intemporal e dialético-histórico. Com razão, François $\mathrm{Ost}^{39}$ analisando a dimensão do tempo no direito, lembra-nos que o entendimento da complexidade do seu sentido não pode abdicar de uma reflexão ontológica a respeito do fundamento invariante que o constitui e encontra justificação na coerência racional de uma dialético-histórica materialidade ética.

Esse fundamento intemporal nos remete aos princípios fundadores que devem estar na base de qualquer ordem jurídica e que mesmo num tempo como o nosso, marcado radicalmente pela incerteza de um relativismo indeterminista, não pode prescindir da aspiração normativa de uma ordem social justa, ou seja, na resolução de cada concreto problema jurídico, a verdade permanente do seu sentido deve se materializar.

Parafraseando Heidegger ${ }^{40}$, que na contramão da voga niilista, esclarece que o fim da metafísica não é o fim da filosofia, mas o fim da filosofia enquanto metafísica podemos dizer que a dissolução pós-moderna do direito fundamentado na metafísica não significa a morte do direito, mas deve apontar para um novo começo, onde o pensamento jurídico é convocado a dar um salto crítico-transcendente para além da representação objetificante da metafísica. Isto quer dizer que a superação da metafísica não exclui a possibilidade de um fundamento axiológico-normativo para o direito, porém apenas exclui, diz-nos 
Castanheira Neves ${ }^{41}$, também evocando Heidegger, um fundamento material identificado com a estrutura noética e dogmático-objetificante da relação sujeito-objeto segundo os pressupostos epistemológicos da metafísica ôntica, ou seja, um fundamento prático-normativo onde a relação sujeito-objeto é substituída pela relação sujeito-sujeito, assim, abandonam-se os fundamentos ôntico-metafísicos, mas não o fundamento em si.

Busca-se, nessa perspectiva, recuperar os fundamentos materiais e axiológico-normativos da razão prática, não mais como entidades dogmáticoabsolutas e auto-subsistentes, mas como condições de possibilidade normativa dialeticamente inserida na historicidade cultural da vida humana. São esses princípios, os valores fundantes, intemporais e metapositivos da positividade jurídica, inscritos na consciência jurídica de uma tradição cultural, como uma verdade permanente da sua humana e autônoma essência, razão pela qual eles estão ao abrigo das mudanças contingenciais da vontade política. Segundo Gadamer, eles remetem para "[...] la realización de una conservación que, em uma confirmación constantemente renovada, hace posible la existência de algo que es verdad"42. Por isso, a legitimidade prática da sua normatividade estende seu poder vinculante sobre o tempo porque, ao mesmo tempo, está para aquém da existência histórica; projeta-se para além dela, sem jamais deixar de estar em imanência com ela, numa simultaneidade intemporal com qualquer presente.

Refletindo o sentido essencial do direito que o revela como uma humana alternativa, Castanheira Neves ${ }^{43}$ esclarece o equívoco do pensamento jurídico que tantas vezes confundiu e, principalmente hoje, confunde o direito com aquilo que ele não é, eis que, nem sempre uma ordem social, normativa e coercitivamente estruturada, constitui uma ordem de direito como nos demonstram os históricos despotismos e as atuais tendências de planificação da vida social logicamente administrada pelos critérios formais da racionalidade técnico-científica.

\section{CONCLUSÕES}

Como este estudo procurou demonstrar a idéia de direito na tradição da cultura ocidental, desde os seus primórdios, fundamentou-se nos princípios transcendentais da metafísica.

O positivismo jurídico, ao tentar libertar-se dela, reafirmou-a radicalmente, ao reduzir a normatividade jurídica na objetificação dogmática da sua entificação positiva.

Dessa redução científico-neutral, derivou uma metodologia jurídica alheia às contingências práticas da realidade social, que suprimiu a autonomia do direito e transformou-o tecnicamente em instrumento de dominação política.

Assim, contrariando a sua motivação onto-gnoseológica, a ilusão metafísica do positivismo, ao tentar concretizar uma lógico-formal certeza 
metódica, desvirtuou a práxis judicativa da intenção prático-normativa do direito em favor de uma abstração teorética.

A crise do relativismo pós-moderno evidencia radicalmente o equívoco positivista e impõe ao pensamento jurídico a busca de alternativas críticas que tenham a consciência de que a essência do problema jurídico não é lógicosistemática e, sim, prático-problemática.

Para que uma ordem social constitua uma ordem de direito, faz-se necessária uma condição que Ihe é essencial: a condição ética, com a sua correlativa exigência axiológica de uma ordem justa e não apenas eficaz. $O$ dever-ser jurídico pressupõe um fundamento de validade axiológico-normativo, pois o direito é "[...] uma categoria ética, não uma categoria já estratégica, já "científica" _ o seu universo é prático-axiológico, não apenas decisório e técnico-intelectual" ${ }^{\prime 4}$, isso indica que o direito não está na redução entificadora e dogmático-metafísica de um abstrato sistema normativo pressuposto, mas se revela crítico-problematicamente e criativamente na sua realização prática, ou seja, na concreto-material prospecção prudencial do justo.

Portanto, podemos constatar acentuado que no vazio deixado pela perda dos referenciais do universalismo metafísico e, para além da diluição fragmentária do hipercientificismo do nosso tempo, mais do que nunca se impõe ao pensamento jurídico, frente ao perigo real do desaparecimento do direito, esclarecer e contribuir para recuperar o seu verdadeiro e humano sentido que o revela como uma categoria ética, cuja expressão axiológiconormativa reivindica para poder afirmar-se com histórica autenticidade, uma necessária autonomia frente ao finalismo contingencial da vontade do poder político.

\title{
THE OCCIDENTAL JURIDICAL CONCEPTION SINCE THE CLASSICAL ANTIQUITY UNTIL THE MODERN DAYS DEVELOPED EPISTEMOLOGICALLY
}

\begin{abstract}
A concept of law based in the presupposed of the metaphysical rationality. By reason of this the crisis of the post modern relativism whish today disturbs and divides the logical safeties of the metaphysics, affects the law radically, menacing its historical purpose and evidencing the real possibility of its disappearance, in a cultural context that is demanding manners social regulation more adapted to the complicated exigencies of the technologicalscientific-societies.
\end{abstract}

Keywords: Crisis. Law. Metaphysics. Modern days. Post modern days. 


\section{NOTAS}

Professor do Programa de Pós-Graduação em Direito da Universidade do Vale do Rio dos Sinos - Unisinos.

1 PLATÃO. As leis. In. Obras Completas. Tradução de Francisco de P. Samaranch. Madrid: Aguilar, p. 1355.

HEIDEGGER, Martin. Nietzsche. Tradução de Juan Luis Vermal. Barcelona: Ediciones Destino, 2000, v. 2, p. 334.

3 ARISTÓTELES, Política. Tradução de Antônio Campelo Amaral e Carlos de Carvalho Gomes. Lisboa: Veja, 1998, p. 55.

Idem, p. 259.

CASTANHEIRA NEVES, António. O instituto dos "assentos" e a função jurídica dos supremos tribunais. Coimbra: Editora Coimbra, 1983, p. 495.

Idem, p. 496-497.

ORTOLAN, M. Compendio del derecho romano. Tradução de Francisco Perez de Anaya y Melquiades Peres Rivas. Buenos Aires: Atalaya, 1947, p. 13.

8 AQUINO, Tomás de. Suma teológica. Tradução de Alexandre Corrêa. Caxias do Sul: Sulina, 1980, v. 1, p. 34.

Idem, p. 894.

Idem, v. 4, p. 1737.

WIEAKER, Franz. História do direito privado moderno. Tradução de A. M. Botelho Espanha. Lisboa: Fundação Calouste Gulbenkian, 1993, p. 43.

VAZ, Henrique C. de Lima. Escritos de filosofia. São Paulo: Loyola, 1988, v. 2, p. 165.

${ }^{13}$ KANT, Emmanuel. Crítica da razão prática. Tradução de Afonso Bertagnoli. Rio de Janeiro: Ediouro, s.d., p. 31.

14 HEGEL, Georg Friedrich Wilhelm. Princípios da filosofia do direito. Tradução de Orlando Vitorino. São Paulo: Martins Fontes, 2000, p. 226.

15 COMTE, Augusto. Curso de filosofia positiva. In: Os pensadores. Tradução de José Arthur Gianotti. São Paulo: Nova Cultural, 1991, p. 4.

16 COMTE, Augusto. Discurso preliminar sobre o conjunto do positivismo. In: Os pensadores. São Paulo: Nova Cultural, 1991, p. 47.

17 Idem, ibidem.

18 HABERMAS, Jürgen. Conhecimento e Interesse. Tradução de José N. Heck. Rio de Janeiro: Guanabara, 1987, p. 90.

${ }^{19}$ Idem, p. 100.

${ }^{20}$ BODENHEIMER, Edgar. Ciência do direito. Tradução de Enéas Marzano. Rio de Janeiro: Forense, 1966, p. 110.

${ }^{21}$ PERELMAN, Chäim. Ética e direito. Tradução de Maria Ermantina Gusmão. São Paulo: Martins Fontes, 1999, p. 386.

${ }^{22}$ ROUSSEAU, Jean-Jacques. O contrato social. Tradução de Rolando Roque da Silva. São Paulo: Cultrix, 1995, p. 47.

23 COTTA, Sérgio. O desafio tecnológico. Tradução de Manuel Reis. Coimbra: Armênio Amado, 1971, p. 163.

24 HEGEL, Georg Friedrich Wilhelm. Fenomenologia do Espírito. Tradução de Paulo Meneses. Petrópolis: Vozes, v. I, II, 1997, p. 10, 11.

25 HEIDEGGER, Martin. Nietzsche. Tradução de Juan Luis Vermal. Barcelona: Ediciones Destino, 2000, v. 2., p. 125.

26 HABERMAS, Jürgen. Pensamento Pós-Metafísico. Tradução de Flávio Beno Siebeneicher, Rio de janeiro: Tempo Brasileiro, 1990, p. 59.

27 WELLMER, Albrecht. Sobre la Dialética de Modernidad y Postmodernidad. Tradução de José Luis Arántegui: Madrid: Visor, 1992, p. 51.

28 FARIA, José Eduardo. O Direito na Economia Globalizada. São Paulo: Malheiros, 1999., p. 15.

29 ARNAUD, André-Jean. O Direito entre Modernidade e Globalização. Tradução de Patrice Charles Wuillaume. Rio de Janeiro: Renovar, 1999, p. 218, 219.

30 LUHMANN, Niklas. Sistemas Sociales. Tradução de Silvia Pappe e Brunilde Erker. México: Alianza, [s.d.], p. 25.

31 LUHMANN, Niklas. Sociologia do Direito. Tradução de Gustavo Bayer. Rio de Janeiro: Tempo Brasileiro, 1985. v. II, p. 60. 
32 TEUBNER, Günther. O Direito como Sistema Autopoiético. Tradução de José Engrácia Antunes. Lisboa: Fundação Calouste Gulbenrkian, 1989, p. 64, 65.

33 BALLESTEROS, Jesús. Sobre el Sentido del Derecho. 2. ed. Madrid: Tecnos, 1986, p. 40, 41.

34 CASTANHEIRA NEVES, António. O Direito como Alternativa Humana. In Digesta. Coimbra: Editora Coimbra, 1995, v. I, II, p. 294, 295.

35 Idem, p. 300.

36 HABERMAS, Jürgen. Direito e Democracia. Tradução de Beno Siebeneichler. Rio de Janeiro: Tempo Brasileiro, 1997, p. 171.

37 CASTANHEIRA NEVES, António. O Direito Hoje com que Sentido? Lisboa: Instituto Piaget, 2002, p. 47.

38 SICHES, Luis Recaséns. Nueva Filosofia de la Interpretación del Derecho. México: Porrúria, 1973, p. 147.

39 OST, François. O Tempo do Direito. Tradução de Maria Fernanda Oliveira. Lisboa: Instituto Piaget, 1999, p. 95, 96.

40 HEIDEGGER, Martin. O Fim da Filosofia e a Tarefa do Pensamento. In: Os pensadores. Tradução de Ernildo Stein. São Paulo: Abril Cultural, 1979, p. 67.

41 CASTANHEIRA NEVES, António. Metodologia Jurídica.: Coimbra: Coimbra-Editora, 1993, p. 46 [SS].

42 GADAMER, Hans-Georg. Verdad y Método. Tradução de Ana Agud Aparicio e Rafael de Agapito. Salamanca: Sígeme, 1997, p. 349 [SS].

43 CASTANHEIRA NEVES, António. O Direito como Alternativa Humana. In Digesta. Coimbra: Editora Coimbra, 1995, v. I, II, p. 287 [SS].

$44 \quad$ Idem, p. 308.

\section{REFERÊNCIAS}

AQUINO, Tomás de. Suma teológica. Tradução de Alexandre Corrêa. Caxias do Sul: Sulina, 1980, v. 1

ARISTÓTELES. Política. Tradução de Antônio Campelo Amaral e Carlos de Carvalho Gomes. Lisboa: Veja, 1998.

ARNAUD, André-Jean. O Direito entre Modernidade e Globalização. Tradução de Patrice Charles Wuillaume. Rio de Janeiro: Renovar, 1999.

BALLESTEROS, Jesús. Sobre el Sentido del Derecho. 2. ed. Madrid: Tecnos, 1986.

BODENHEIMER, Edgar. Ciência do Direito. Tradução de Enéas Marzano. Rio de Janeiro: Forense, 1966.

CASTANHEIRA NEVES, António. Metodologia Jurídica. Coimbra: Coimbra, 1993.

CASTANHEIRA NEVES, António. O Direito como Alternativa Humana. In Digesta. Coimbra: Editora Coimbra, 1995, v. I, II.

CASTANHEIRA NEVES, António. O Direito Hoje com que Sentido? Lisboa: Instituto Piaget, 2002.

CASTANHEIRA NEVES, António. O instituto dos "assentos" e a função jurídica dos supremos tribunais. Coimbra: Editora Coimbra, 1983.

COMTE, Augusto. Curso de filosofia positiva. In: Os Pensadores. Tradução de José Arthur Gianotti. São Paulo: Nova Cultural, 1991. 
COMTE, Augusto. Discurso preliminar sobre o conjunto do positivismo. In: Os Pensadores. São Paulo: Nova Cultural, 1991.

COTTA, Sérgio. O Desafio Tecnológico. Tradução de Manuel Reis. Coimbra: Armênio Amado, 1971.

FARIA, José Eduardo. O Direito na Economia Globalizada. São Paulo: Malheiros, 1999.

GADAMER, Hans-Georg. Verdad y Método. Tradução de Ana Agud Aparicio e Rafael de Agapito. Salamanca: Sígeme, 1997.

GENY, François. Método de interpretación y fuentes en derecho privado positivo. Madrid: Hijos de Réus, 1902.

HABERMAS, Jürgen. Conhecimento e Interesse. Tradução de José N. Heck. Rio de Janeiro: Guanabara, 1987.

HABERMAS, Jürgen. Direito e Democracia. Tradução de Beno Siebeneichler. Rio de Janeiro: Tempo Brasileiro, 1997.

HABERMAS, Jürgen. Pensamento Pós-Metafísico. Tradução de Flávio Beno Siebeneicher, Rio de janeiro: Tempo Brasileiro, 1990.

HEGEL, Georg Friedrich Wilhelm. Fenomenologia do Espírito. Tradução de Paulo Meneses. Petrópolis: Vozes, v. I, II, 1997.

HEGEL, Georg Friedrich Wilhelm. Princípios da filosofia do direito. Tradução de Orlando Vitorino. São Paulo: Martins Fontes, 2000.

HEIDEGGER, Martin. Nietzsche. Tradução de Juan Luis Vermal. Barcelona: Ediciones Destino, 2000, v. 2.

HEIDEGGER, Martin. O Fim da Filosofia e a Tarefa do Pensamento. In: Os pensadores. Tradução de Ernildo Stein. São Paulo: Abril Cultural, 1979.

KANT, Emmanuel. Crítica da razão prática. Tradução de Afonso Bertagnoli. Rio de Janeiro: Ediouro, s.d.

LUHMANN, Niklas. Sistemas Sociales. Tradução de Silvia Pappe e Brunilde Erker. México: Alianza, [s.d.].

LUHMANN, Niklas. Sociologia do Direito. Tradução de Gustavo Bayer. Rio de Janeiro: Tempo Brasileiro, 1985. v. II.

MONTESQUIEU, Charles. Do espírito das leis. Tradução de Gabriela de Andrada Dias Barbosa. São Paulo: Brasil Editora, 1960.

ORTOLAN, M. Compendio del derecho romano. Tradução de Francisco Perez de Anaya y Melquiades Peres Rivas. Buenos Aires: Atalaya, 1947.

OST, François. O Tempo do Direito. Tradução de Maria Fernanda Oliveira. Lisboa: Instituto Piaget, 1999.

PERELMAN, Chäim. Ética e direito. Tradução de Maria Ermantina Gusmão. São Paulo: Martins Fontes, 1999.

PLATÃO. As leis. In: Obras completas. Tradução de Francisco de P. Samarauch. Madrid: Aguilar.

PLATÃO. Protágoras. In: Obras completas. Tradução de Francisco de P. Samarauch. Madrid: Aguilar, 1993. 
ROUSSEAU, Jean-Jacques. O Contrato Social. Tradução de Rolando Roque da Silva. São Paulo: Cultrix, 1995.

SICHES, Luis Recaséns. Nueva Filosofia de la Interpretación del Derecho. México: Porrúria, 1973.

TEUBNER, Günther. O Direito como Sistema Autopoiético. Tradução de José Engrácia Antunes. Lisboa: Fundação Calouste Gulbenrkian, 1989.

VAZ, Henrique C. de Lima. Escritos de filosofia. São Paulo: Loyola, 1988, v. 2.

WELLMER, Albrecht. Sobre la Dialética de Modernidad y Postmodernidad. Tradução de José Luis Arántegui: Madrid: Visor, 1992.

WIEAKER, Franz. História do direito privado moderno. Tradução de A. M. Botelho Espanha. Lisboa: Fundação Calouste Gulbenkian, 1993.

Recebido para publicação 13/11/2008

Aceito para publicação 14/012009 